\title{
Coastal Retreat and Sedimentation during the Last 3000 Years. Atlantic Coast of NW Spain
}

\author{
Ramón Blanco-Chao* ${ }^{\mathbb{D}}$, Manuela Costa-Casais $\mathbb{D}$, Daniel Cajade-Pascual and \\ Gonzalo Gómez-Rey \\ Departamento de Geografía, Universidad de Santiago de Compostela, 15782 Santiago, Spain \\ * Correspondence: ramon.blanco@usc.es; Tel.: +34-8818-11000 (ext. 12675)
}

Received: 12 July 2019; Accepted: 22 September 2019; Published: 24 September 2019

\begin{abstract}
During the last glaciation, thick nival and periglacial sediments buried large sectors of the NW coast of Spain. The sediments were mostly eroded by the rising sea level during the Holocene, but in several places they remain, forming sedimentary cliffs. Radiocarbon dates obtained at the topmost layers of these cliffs prove that continental sedimentation was active until very recent times, followed by a retreat of the cliffs. During the first stages of the transgression, the erosion of the cliffs and the changes in the coastal system were controlled by the rising sea-level. Once the sea-level stabilized, the exhumation of inherited landforms, the supply of sediments, and a continuous continental sedimentation became the main factors. The last stages of cliff retreat were almost synchronous with the sedimentation of the upper layers of the deposits.
\end{abstract}

Keywords: sedimentary cliffs; coastal change; late Holocene; human activity

\section{Introduction}

The eustatic, isostatic, and tectonic components of relative sea-level, as well as sediment availability, are the main factors driving the morphodynamics of transgressive coastal systems, but in the evolution of a sedimentary cliff under a rising sea level the intervening factors are quite complex. The retreat of the cliff-front is caused by wave action and slope instability, with changes in the retreat rate modulated by sea-level oscillations, wave action, sediment availability, and the exhumation of rock landforms. The climatic changes that took place during the Holocene have been accompanied by changes in wave environment, which is the main energy input in coastal dynamics.

The sediment supply depends largely on the geomorphological processes that dominated during the previous regressive stage in the areas that were inundated by the rising sea-level. In high and mid latitudes, many present parts of the coasts with coarse clastic beaches are located in areas that were subjected to periglacial and glacial processes. Paraglacial coasts are those in which glacial landforms and sediments have a strong influence in present morphodynamics [1]. These glacioisostatically uplifted coasts are characterized by a high availability of sediments derived from the erosion of glacial tills. In contrast, coast which experienced periglacial processes are usually isostatically stable and are covered by sediments with a higher variability of facies. [2]. We defined para-periglacial coasts as those in which Holocene evolution has been influenced by the erosion of periglacial and fluvio-nival deposits by the Holocene rising sea-level [3]. In the northwestern coast of the Iberian Peninsula these deposits were formed since the middle Weichselian glaciation to the beginning of the Holocene, although there are sedimentological variations related to local topographic conditions [4-8]. One of the most important factors in the para-periglacial coastal systems of the NW Spain is that the erosion of the continental deposits by the Holocene rising sea-level leaded to the exhumation of ancient coastal landforms, shaped during the last interglacial [3,8,9]. 
There is no precise data on the changing relative sea-level in NW Spain, but the available data suggests that the sea-level reached its present position after $3500 \mathrm{yr}$ BP. Studies conducted in coastal lagoons in the Atlantic coast of the Iberian Peninsula confirmed that in most of them marine conditions were established around 6-5 ka BP and that from 5 to $3 \mathrm{ka} \mathrm{BP}$ the rate of sea-level rise decreased and the lagoons were closed by sand barriers [10-14]. More recently, it was confirmed that sea-level was still below the present one by $3500 \mathrm{yr} \mathrm{BP}$ and that the present sea-level was probably stabilized after that date $[15,16]$. Research conducted on marine sediments in the Atlantic rias and on the continental platform identified several changes in the marine conditions during the last $3 \mathrm{ka}$. These changes were synchronous with oscillations of the NAO index, suggesting consequent variations in the upwelling system [17-19]. Recent investigations found that a pronounced change in the energetic conditions in the Galician coast, from a storm regime to a low-energy environment, may have happen between 2850-2200 cal. yr BP [17,19]. For more recent periods, the reconstruction of the northern hemisphere troposheric circulation suggests an abrupt change around $1400 \mathrm{AD}$ from a weaker atmospheric circulation during the Medieval Warm Period to a period of increasing storminess during the Little Ice Age [20,21], which was also identified in the wave regime [19].

This work focuses on the evolution of para-periglacial coastal systems since the stabilization of sea-level in the late Holocene in NW Spain. In previous works we highlighted the fact that there was evidence of very recent episodes of retreat in one cliff-deposit located in the Ria of Muros-Noia [3,8,9]. In order to verify if this was a local or more regional feature, we studied the previous cliff-deposit and a new one located far from it but in the same region in more detail. We aimed to determine whether late Holocene coastal retreat is regional, and that there was an almost continuous supply of sediment from the continental areas. The results suggest that the coastal systems studied attained equilibrium with the present conditions very recently. The Late Holocene evolution was more complex than a simple linear cliff retreat as the sea-level rose. Consequently, the factors involved in this evolution arise as important controls in the coastal response to future sea-level rise.

\section{Regional Setting}

The Caamaño and Oia cliff-deposits are located in the Atlantic coast of the NW of the Iberian Penisula, at the southern margin of the Ria of Muros and Noia and between Cape Silleiro and the mouth of the Miño river, respectively; the distance between them is $80 \mathrm{~km}$ (Figure 1). The sedimentology of these cliff-deposits was presented in previous studies $[4,5,8,9]$.

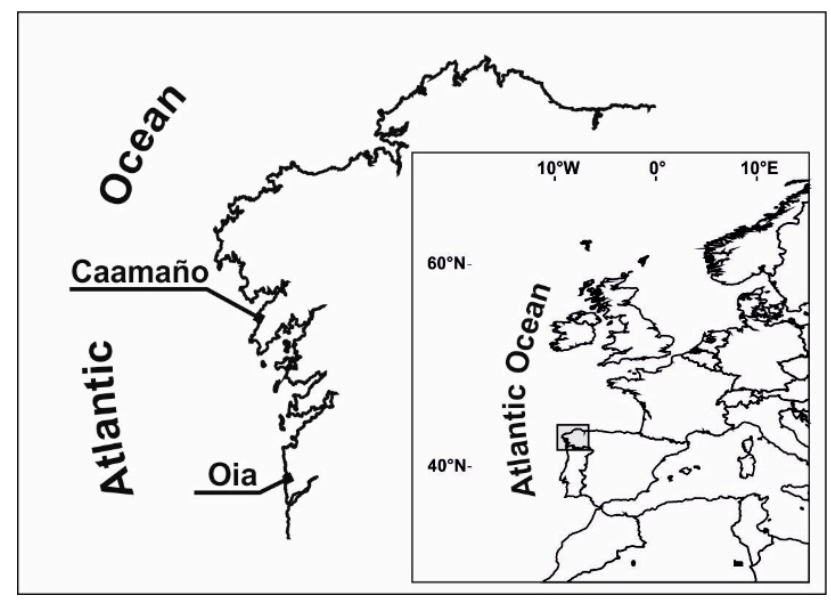

Figure 1. Location of the studied sedimentary cliffs.

Both coastal sectors are characterized by high wave energy. The coast of Caamaño is exposed to waves from the NW and W but more protected from SW waves. Sixty percent of waves range between 1 and $2 \mathrm{~m}$ of significant height and their period varies from 9 to $12 \mathrm{~s}$. The coast at Oia is a more energetic sector because it is exposed to waves coming from the NW, W, and SW, with significant 
height between 1 and $3 \mathrm{~m}$ and periods of 10 to $14 \mathrm{~s}$ representing $40 \%$ of the total. The spring tidal range is $3.75 \mathrm{~m}$, reaching $4 \mathrm{~m}$ under storm surge conditions.

The cliff-deposit of Caamaño is located at the south margin of the Ria of Muros-Noia and infills a palaeo-embayment, with coarse periglacial sediments in the flanks derived from the old cliffs and finer sediments in the central section. The cliff is fronted by a shore platform truncating metamorphic rocks with intrusions of granitic dykes. At the back of the cliff there is a coastal plain of 3-4 km in width, between the Barbanza range, that reaches elevations of $650 \mathrm{~m}$ a.s.l., (Figure 2).
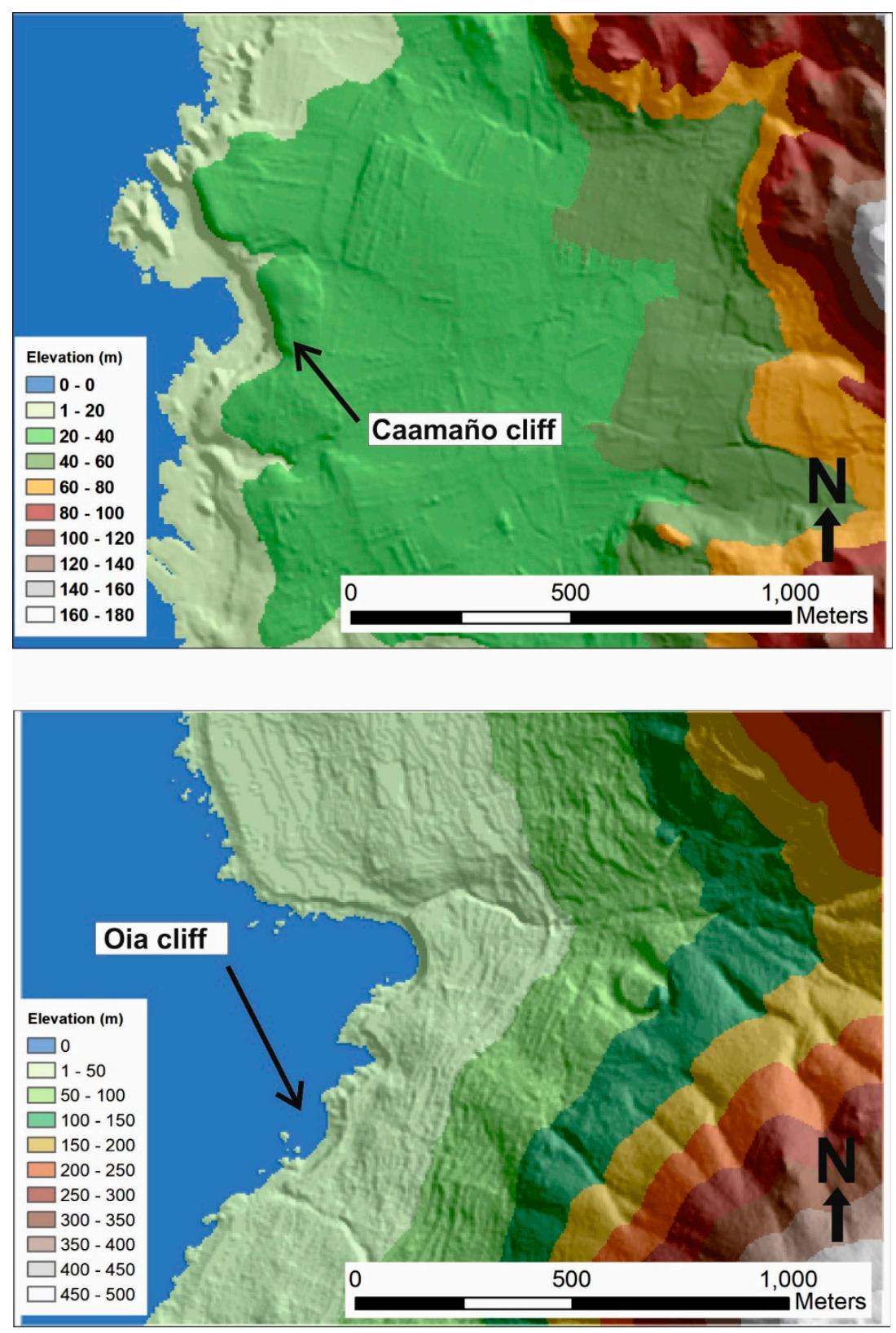

Figure 2. Topography of the inland of both sectors.

The cliff-deposit of Oia is located at the foot of the mountains of A Groba in a narrow embayment, fronted by a coarse-grained beach that rests on the upper section of a wide shore platform developed on granitic rocks. The boulder beach has a well-developed gradient in clast size, decreasing from north to south. Contrary to the Caamaño cliff, this coastal sector is characterized by the presence of coastal mountains attaining elevations of up to $600 \mathrm{~m}$, which are dissected on their seaward slopes by valleys that usually end in small embayments at the coast (Figure 2). 


\section{Materials and Methods}

We sampled two sedimentary sequences, one was located in Caamaño and the other in Oia. The maximum thickness of the Caamaño sequence is $800 \mathrm{~cm}$ and the maximum thickness at Oia is $725 \mathrm{~cm}$. Samples was taken every $5 \mathrm{~cm}$ except in layers rich in coarse material where this resolution was not always possible. The total number of samples collected in Caamaño was 114 and in Oia 56. As this work is centered in the Late Holocene evolution of these coastal systems, only the results for the upper layers of the deposits are presented. The maximum depths from the top of the cliffs of the studied samples were $215 \mathrm{~cm}$ in Caamaño and $40 \mathrm{~cm}$ in Oia.

Grain size analysis was made on the fine earth separating three fractions (coarse sand: $2-0.2 \mathrm{~mm}$; medium+fine sand: $0.2-0.05 \mathrm{~mm}$; and silt+clay: $<0.05 \mathrm{~mm}$ ). Description of the samples was made according to FAO guidelines [22]; the color of dry samples was determined according to the Munsell Soil Colour Chart [23].

Selected samples were sent for radiocarbon dating. In the Caamaño profile the samples for radiocarbon dating were selected according the position of the samples in the sedimentary sequence close to erosive discontinuities. In the Oia profile we selected four dating the samples at the top of the coarser layers, to determine when the accumulation started or the former soil was truncated (Figure 3 and Table 1). The fine fraction $(<2 \mathrm{~mm}$ ) of the samples for radiocarbon dating were shaken in ultrapure distilled water and filtrated on a $50 \mu \mathrm{m}$ mesh-size sieve, removing sand, roots, and some undecomposed organic remains to concentrate the organic matter of the sediments.

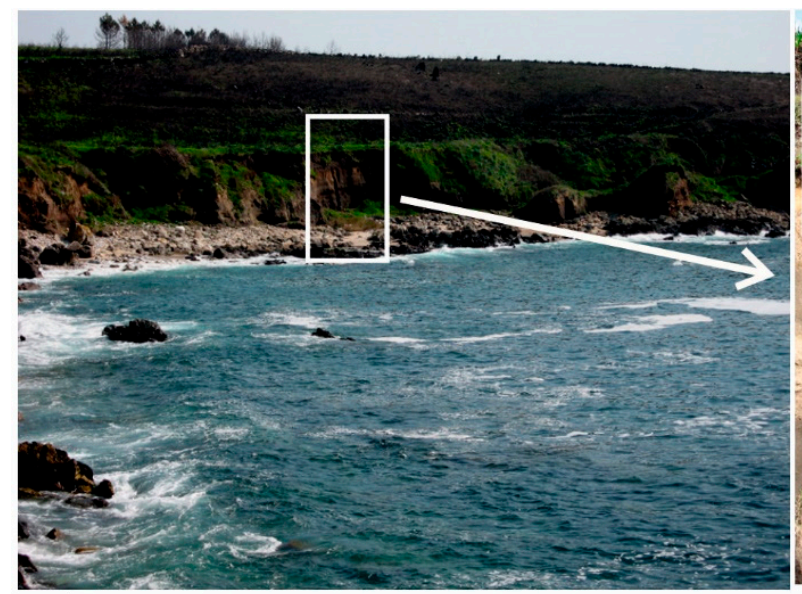

a

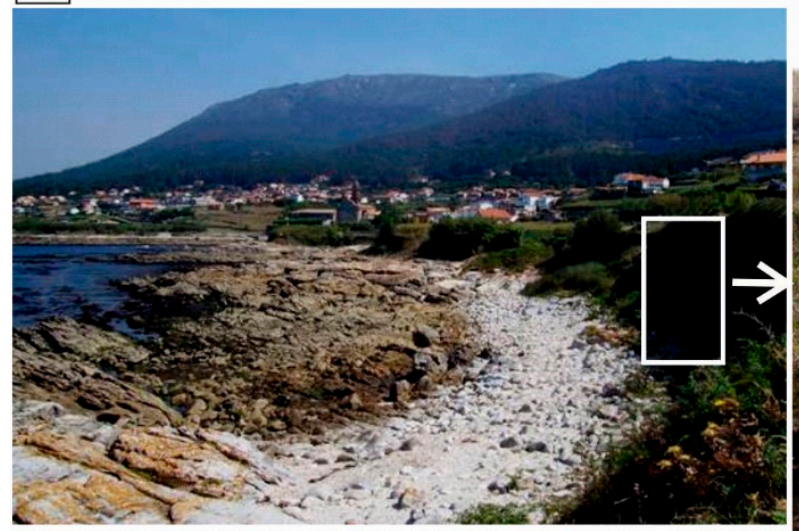

b
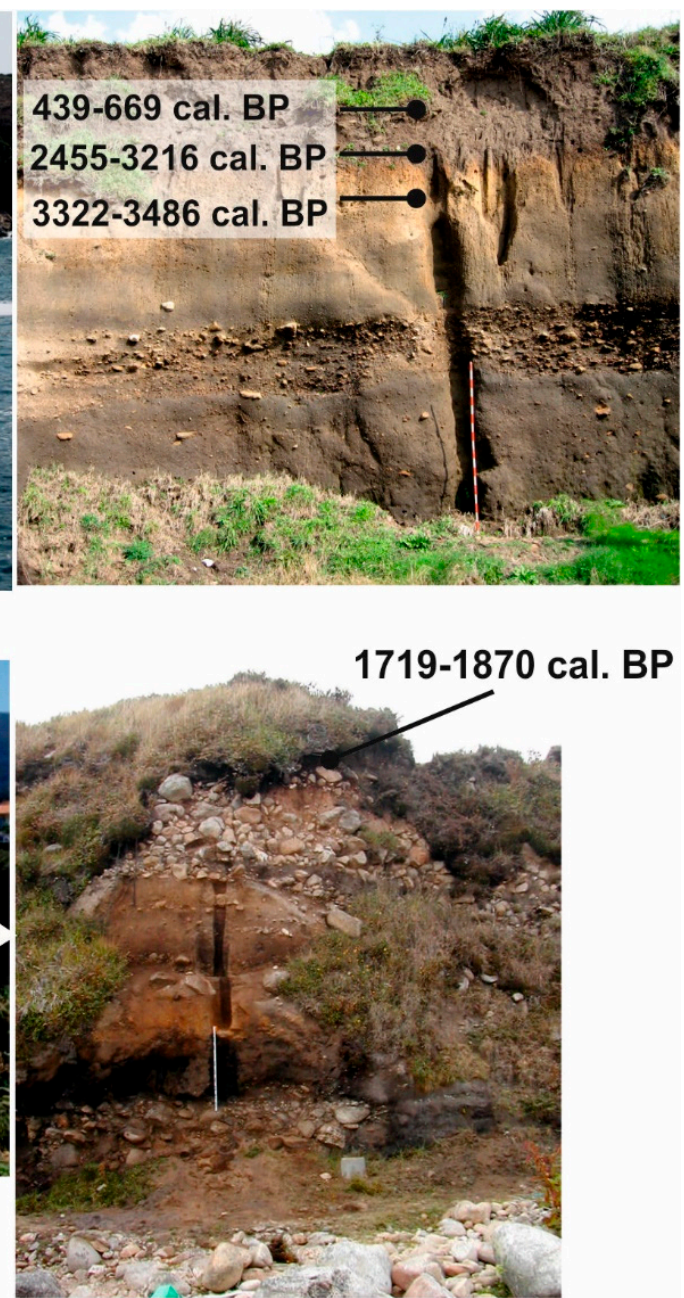

Figure 3. Holocene radiocarbon dates obtained in the sedimentary cliffs of (a) Caamaño and (b) Oia. 
Table 1. Radiocarbon dates cited in the text.

\begin{tabular}{ccccc}
\hline Sample & Site & 14C yr. BP & 2 $\sigma$ cal yr. BP & Source \\
\hline GrN22279 & Caamaño & $530 \pm 80$ & $440-670$ & Trenhaile et al. (1999) \\
GrN22280 & Caamaño & $2720 \pm 140$ & $2455-3215$ & Trenhaile et al. (1999) \\
Ua-33774 & Caamaño & $3180 \pm 50$ & $3320-3485$ & This study \\
GrN20506 & Caamaño & $36,050 \pm 1430$ & - & Trenhaile et al. (1999) \\
Ua33776 & Oia & $1860 \pm 30$ & $1720-1870$ & Costa-Casais and Caetano Alves (2013) \\
Ua33777 & Oia & $25,440 \pm 415$ & - & Costa-Casais and Caetano Alves (2013) \\
Ua33780 & Oia & $35,650 \pm 1475$ & - & Costa-Casais and Caetano Alves (2013) \\
\hline
\end{tabular}

The topography of the intertidal shore platforms in front of the cliffs was obtained using a Total Station Leica TC307, and the elevations referred to the astronomical lowest tide. The topographies of the shore platforms were used to calculate the attenuation of waves after breaking.

\section{Results}

In the two cliffs the upper layers studied represent colluvial soils, and consequently their thickness and the sedimentary features depend on their location with respect to the source area. The two profiles show sedimentary discontinuities as stone, gravel, sandy layers, and charcoal accumulations (Figure 3).

In Caamaño the sediment is black (10 YR 2/2) in color, has a very fine crumby structure near the surface and somewhat more developed to subangular blocky structure towards the base; it is slightly plastic, shows no adherence, and has a slightly hard consistency when dry. Most of the gravel is composed of quartz, granite, and paragneiss. Some of the gravels are rounded and some show intense weathering. There are abundant, fine to medium, roots in the upper $30 \mathrm{~cm}$. A stone layer separates the colluvial soils from the underlying Pleistocene sediments (Figure 3). Particle size is dominated by the sand component ( $70 \pm 4 \%$ sands, $45 \pm 4 \%$ coarse sands, $25 \pm 3 \%$ fine sands) and there are almost no changes in particle size distribution with depth.

In Oia the soil material is light brown (10 YR 4/6) in color, changing to more reddish (7.5 YR 4/4) to the base. It has a weak to moderate fine crumby structure with some fine subangular aggregates. The material is plastic to slightly plastic; shows no adherence and a slightly hard consistency when dry. In the upper $20 \mathrm{~cm}$ there are some angular gravels of granite, mica-schists and quartz-rich schists, and fine to medium roots. From this depth to the base there are sparse redish mottles; the coarse material is composed mostly of rounded and flattened gravels of granite and quartz. Pottery remains were also found. The underlying layer may have a Plesitocene age and is represented by a coarse periglacial deposit $[4,9]$.

As mentioned above, the two cliff-deposits are located in different wave environment locations. Caamaño is in a coast section exposed to waves from NW and W, but protected from those arriving from the SW; while Oia is in a more energetic coast, exposed to waves arriving from NW, W, and SW. In the two sites, the high wave energy environment is characterized by long swell waves, potentially with a high erosive capacity. But the amount of wave energy arriving to the sedimentary cliffs is reduced across the intertidal rock surface. As the sedimentary cliff retreated the width of the exhumed shore platform increased, causing a higher attenuation of the energy of waves. The attenuation of waves after breaking was modeled for the shore platforms using a decay function proposed by Trenhaile [24,25]:

$$
F_{w}=0.5 \rho_{w}\left(\mathrm{~h}_{\mathrm{b}}\right) \mathrm{e}^{-k \cdot \mathrm{Ws}}
$$

where $F_{w}$ is the force of a wave reaching the waterline after breaking, $\rho_{w}\left(1025 \mathrm{~kg} \cdot \mathrm{m}^{3}\right)$ is the density of water, $h_{b}$ is the breaking wave depth, $k$ is a surf attenuation constant, and $W_{s}$ is the width of the surf zone from the breakers to the waterline, calculated from topographic profiles. The breaking wave depth was determined assuming the relationship $H_{b} / h_{b}=0.78$, and breaker height $\left(H_{b}\right)$ was calculated from deep water Hs following Komar and Gaughan [26]: 


$$
\mathrm{H}_{\mathrm{b}}=0.39 \mathrm{~g}^{0.2}\left(\mathrm{TH}_{\mathrm{p}}{ }^{2}\right)^{0.4}
$$

Assuming a high attenuation rate, given the roughness of the surface, waves today expend much of their energy on the wide shore platforms, and only the smallest waves reach the waterline with up to $20 \%$ of their initial energy (Figure 4). At spring high tide waves with $\mathrm{Hs}$ of $2 \mathrm{~m}$ preserve $20 \%$ of their energy at a distance from the waterline of $30 \mathrm{~m}$ in Oia and $15 \mathrm{~m}$ in Caamaño. Given the lower slope of the platform waves experience a higher attenuation in Oia.

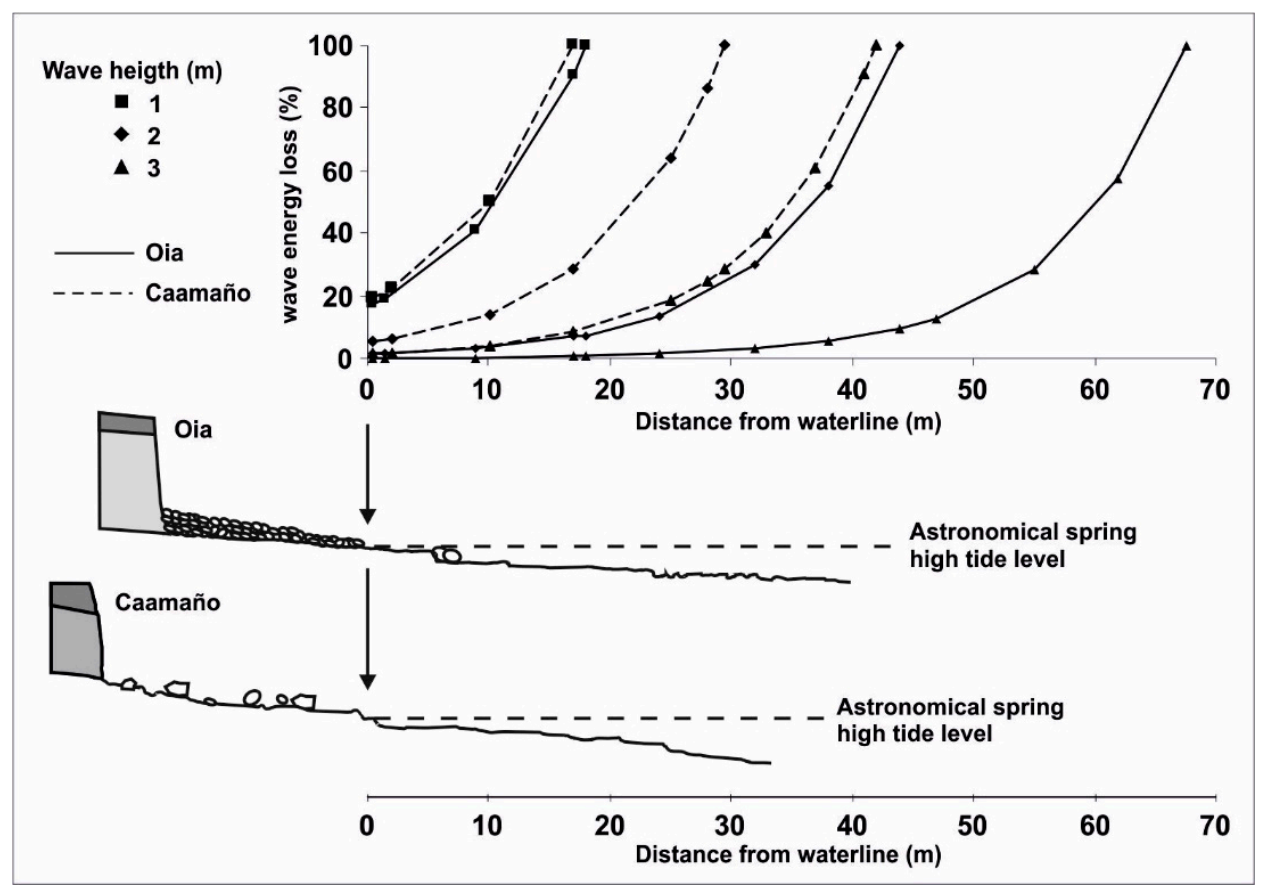

Figure 4. Percentage of wave energy expended on the shore platform of Oia and Caamaño at the spring high tide. The $100 \%$ of wave energy corresponds to breaking. The value of $k$ was 0.1 , which represents high rates of attenuation in a rough surface [25]. Calculations were made using waves of significant heights between 1 to $3 \mathrm{~m}$ with periods between 9 to $14 \mathrm{~s}$. Wave data obtained from Silleiro buoy and Simar-44 1043071 point (Puertos del Estado database).

The ${ }^{14} \mathrm{C}$ dating obtained in Caamaño at $750-755 \mathrm{~cm}$ depth from the top of the cliff provided an age of 36,050 yr BP [9] (Table 1). Three samples taken at 100, 160, and $215 \mathrm{~cm}$ from the top of the cliff gave ${ }^{14} \mathrm{C}$ ages of 550 cal. yr BP (440-670 cal. yr BP at 2 sigma) (GrN-22279), 2835 cal. yr BP (2455-3215 cal. BP) (GrN-22280) [9], and 3400 cal. yr BP (3320-3485 cal. BP) (Ua-33774). The radiocarbon ages indicate a continuous sedimentation during the late Holocene.

The oldest sample dated in Oia provided an uncalibrated age of 35,650 yr BP (Ua-33780) at 195-200 cm depth from the top of the cliff [27]. A sample taken immediately above the coarse periglacial deposit at the southern section of the cliff (at a depth of $45 \mathrm{~cm}$ below the top of the cliff) provided an age of 1795 cal. yr BP (1720-1870 cal. yr BP) (Ua-33776) [27]. A sample below the coarse periglacial level gave an uncalibrated age of $25,440 \mathrm{yr} \mathrm{BP}$ (Ua33777) [27]. The central section of Oia, where fine sedimentary facies are thicker than in the borders, was not dated because of the difficulties to access the cliff face and the dense vegetation covering it. Thus, the dating indicates that the upper $2 \mathrm{~m}$ of the Caamaño cliff were deposited during the last ca. 3400 cal. yr BP, while in the Oia cliff the top $45 \mathrm{~cm}$ were deposited during the last 1800 cal. yr BP.

\section{Discussion}

The sedimentary analyses and the morphodynamics of both sites allowed the reconstruction of the coastal change after the stabilization of the Holocene sea-level. This was characterized by 
a progressively reduction in the rate of cliff retreat as the shore platforms were exhumed, and during this period sediments continued to accumulate on the surface inland of the eroding cliff.

The thickness and sedimentary facies of the continental deposits studied change according with the position of present cliff-deposits with respect to the source area. The hinterland topography, namely altitude, distance to the source area, and aspect were the factors determining the type of sediments [7]. The erosion of the periglacial and snow-melt sediments by the Holocene rising sea-level exhumated the gradient surface of the shore platforms and created a dissipative area that increased in width as the sedimentary cliff retreated. The degree to which wave energy is attenuated on the shore platform depends on the width and geometry of the inherited surface and on the sedimentary facies, thickness, and extension of the sediments deposited on it. Also, the formation of beaches and their geometry are greatly influenced by the size of the clasts supplied by the erosion of the cliffs.

The two cliff-deposits are located in different wave environment locations, although in both the high wave energy environment is characterized by long swell waves, potentially with a high erosive capacity. But the amount of wave energy arriving to the sedimentary cliffs is reduced across the intertidal rock surface. As the sedimentary cliff retreated the width of the exhumed shore platform increased, causing a higher attenuation of the energy of waves. The cliff-deposits of Caamaño and Oia have a vertical profile, which implies that the dated sediments of the top were deposited when the cliff front was in a more seaward position, and that the entire profile retreated after their deposition (Figure 5). As indicated above, the sea-level reached its present position not before $3500 \mathrm{yr}$ BP $[15,16]$. It is evident that when the cliff front was in a more seaward position, in which waves kept much more energy, the retreat rate was probably faster at the first stages after sea-level stabilization. Wave attenuation was enhanced and the retreat rate became slower as the shore platform was progressively exhumated. It must be added that the change to a low wave energy environment identified around 2850-2200 cal. yr BP $[17,19]$ could have been another important factor in the deceleration of the cliff retreat at both studied sites.

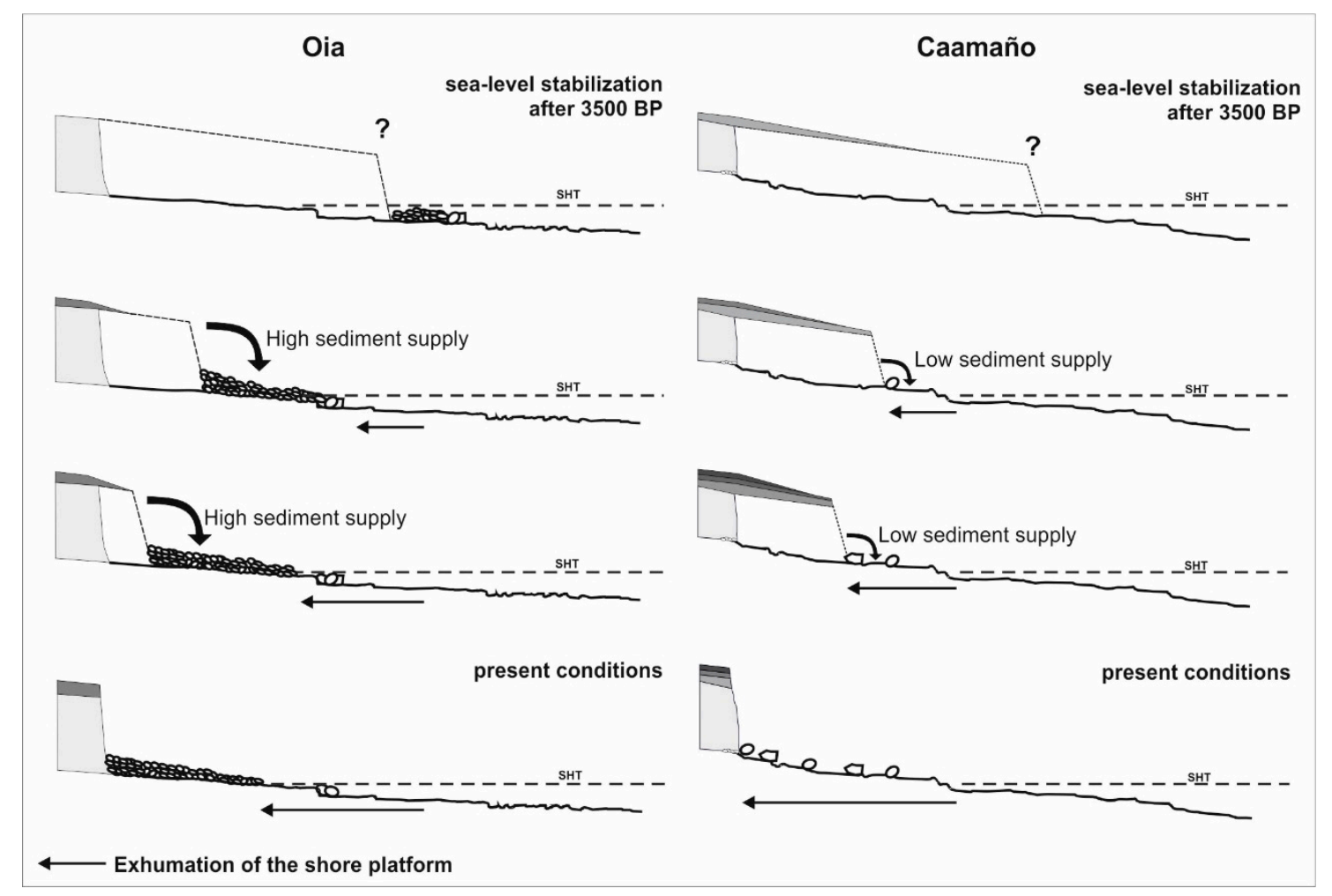

Figure 5. Model of coastal retreat in the two sectors. The exhumation of the inherited shore platform and the sediment supply from the erosion of the cliffs were two of the main factors in the recent evolution. 
Coarse sediments are much more abundant in Oia than in Caamaño, where the sedimentation had a more local source. The erosion of the cliff in Oia supplied an increasing volume of clasts, nourishing a beach that became progressively wider and thicker. In contrast, the sediments in Caamaño are dominated by finer facies, except in the flanks. As a consequence, given the high energy of the sector, the beach developed is smaller and narrower than in Oia. The occurrence of a wide beach was a very important factor, added to the exhumation of the rock surface, to finally stop the erosion of the cliff and its stabilization.

The landward retreat of the cliff and of the beach left evidences in the fronting shore platform of Oia. Using the Schmidt Rock Hammer Test [3] found that abrasion erodes the superficial weathered layers caused by tidal wetting and drying, maintaining a fresh rock surface. In Oia, the erosion of the cliff deposits supplied the clasts and boulders for the fronting beach. As the cliff retreated, the coarse-grained beach moved landward causing an intense abrasion on the shore platform and leaving a broad strip of less weathered rock. The existence of hard and fresh surfaces in high tide elevations not subjected to abrasion today is an inherited characteristic revealing that the cliff retreated very recently.

The chronology and net sedimentation rates obtained for the upper colluvial soils of Caamaño and Oia, suggest two periods of enhanced sediment accumulation/supply (one between ca. 3400-2835 cal. $\mathrm{yr} \mathrm{BP}$ and another in the last 550 years), and a period of lower sediment accumulation (between ca. 2835-550 cal. yr BP). Maximum accumulation seems to have started with the Little Ice Age pointing to a climatic control.

For some areas of NW Spain Martínez-Cortizas and Moares-Domínguez [28] proposed the existence of at least six periods of erosion during the Holocene: 11,000-10,000 yr BP, 8000-7500 yr BP, 5500-5000 yr BP, 4500-4000 yr BP, 1500-1000 yr BP, and a more recent one starting 500 years ago. In a subsequent work carried out in a colluvial soil in the area of Monte Penide (Redondela) [29] identified four erosive/cumulative phases: one that would have begun around the 6500-6290 cal BP, one initiated by $4850-4540 \mathrm{cal}$ yr BP, another by $2315-1950 \mathrm{cal}$ yr BP, and a later one estimated to have occurred between 800 and the $500 \mathrm{cal}$ yr BP.

Nevertheless, the phase with lowest sedimentation rate also coincides with a period of abrupt Holocene climate change (the 2.8 ka event) [30,31], while the oldest phase of enhanced sediment deposition in Caamaño (ca- 3400-2835 cal yr BP) does not seem to have been climatically induced. Thus, not all phases seem to be related to climate change, and for those coevals with Holocene abrupt climate changes the response of the system was not homogeneous, which suggests that other factors may also have been involved.

A number of geomorphological, geochemical, and pollen studies on landscape evolution in NW Spain, carried out in peatlands, fluvial valley infillings, colluvial soils, and coastal deposits, have provided a precise environmental reconstruction for the upper Holocene. These studies reveal that human activity may have been involved in the acceleration of soil erosion during the last 6000 years [32-39]. The ultimate cause was a progressive forest decline due to the use of fire and clear cutting [40]. In some continental settings (i.e., small basins and footslopes), recurrent soil erosion and sedimentation resulted in the formation of deep, black colluvial soils-known as Atlantic Rankers-[39-41], with properties similar to those of the upper sections of the Caamaño and Oia deposits. Evidences of increased sedimentation in coastal systems after human-induced soil erosion have also been recorded in other Atlantic coastal systems of the Iberian Peninsula [14].

Around $3000 \mathrm{cal}$. yr BP, at the start of the local Iron Age, the studies point to increased human pressure: a further forest decline and an increase in charcoal content in sediments and soils [42,43], the start of atmospheric metal pollution [44-46], increased accumulation of soil dust in peatlands [35], an acceleration of soil acidification [37,39], and new episodes of erosion of the slope soils and deposition/colluviation in the lowlands [36,47].

In agreement with these studies, our results suggest that since the $3000 \mathrm{cal}$. yr BP the direct result of this enhanced erosion of the slope soils near the coast led to the accumulation of up $2 \mathrm{~m}$ of sediments 
on the top of the retreating bluffs. The start of this phase coincides with the transition from Late Bronze Age to the local Iron Age, and although this change has been attributed to climatic variations, the enhanced continental sediment supply of the last 3 ka may also have been forced by increased human-induced soil erosion.

\section{Conclusions}

Radiocarbon dates on the top layers of sedimentary cliffs prove the existence of coastal retreat in the last 3000 years, after the stabilization of the Holocene rising sea-level. In the two sites studied the continental sedimentation during this period was very different, with up to $2 \mathrm{~m}$ of sediments in Caamaño and $1 \mathrm{~m}$ in Oia. Although the rates of continental sedimentation were controlled by the hinterland morphology and the type of geomorphological processes during the glaciation, the present study suggests that the occurrence of phases of continental sedimentation after the stabilization of the sea-level, probably triggered by human-induced erosion, is a regional feature.

The retreat of the described sedimentary cliffs during the first stages of the transgression was probably driven by a rapid sea-level rise. But the sedimentary evidence suggests that during the last $3 \mathrm{ka}$ BP the erosion of the cliff-deposits was mainly a process of coastal re-organization after the sea-level reached its present elevation.

Once the present sea-level was established, the front of the cliffs remained subject to erosion. The cliff front retreated, exhuming the inherited shore platform, which progressively enhanced wave attenuation over a progressively wider surface.

Wave attenuation, like at present, occurred as soon as the upper segments of the shore platforms were exhumed. These upper segments of the Caamaño shore platform are at an elevation above the astronomical high tide, and only long and high storm waves can reach the cliff front, which leads to a more pronounced reduction in the rate of cliff retreat.

In Oia, the upper segment of the shore platform is also at the high tide elevation. But added to that, the higher amount of coarse clasts in the cliff sediments nourished a wide gravel-to-boulder beach at the cliff foot that created another element for cliff protection. In Caamaño, the lower availability of clasts in the cliff sediments did not allow the development of a wide beach.

The wave attenuation caused by the exhumation of the shore platforms of Oia and Caamaño and the development of a boulder beach in Oia lead to the reduction of cliff erosion by waves. This reduction of wave erosion enabled the deposition of the continental sediments on the top of the retreating cliff, proving the existence of a very recent coastal retreat and stabilization after 1720-1870 and before $439-669$ yr BP.

Author Contributions: Conceptualization: R.B.-C. and M.C.-C.; Investigation R.B.-C., M.C.-C., D.C.-P. and G.G.-R. Data analysis: R.B.-C., M.C.-C., D.C.-P. and G.G.-R. Writing-Original Draft Preparation: R.B.-C.; Writing-Review \& Editing: M.C.-C., D.C.-P. and G.G.R.

Funding: This research received no external funding.

Conflicts of Interest: The authors declare no conflict of interest.

\section{References}

1. Forbes, D.L.; Syvitski, J.P.M. Paraglacial coasts. In Coastal Evolution. Late Quaternary Shoreline Morphodynamics, 1st ed.; Carter, R.W.G., Woodroffe, C.D., Eds.; Cambridge University Press: Cambridge, UK, 1994; pp. $373-424$.

2. Haslett, S.K.; Curr, R.H.F. Stratigraphy and palaeoenvironmental development of Quaternary coarse clastic beach deposits at Plage de Mezpeurleuch, Brittany (France). Geol. J. 2001, 36, 171-182. [CrossRef]

3. Blanco-Chao, R.; Pérez Alberti, A.; Trenhaile, A.S.; Costa-Casais, M.; Valcárcel Díaz, M. Shore platform abrasion in a para-periglacial environment, Galicia, northwestern Spain. Geomorphology 2007, 83, $136-151$. [CrossRef]

4. Costa-Casais, M. Análise Sedimentaria e Reconstrucción Paleoambiental da Costa Atlántica de Galicia. Ph.D. Thesis, Servicio de Publicacións e Intercambio Científico da U.S.C, Santiago de Compostela, Spain, $2001 ; 236$. 
5. Costa-Casais, M.; Moares Domínguez, C.; Martínez-Cortizas, A. Caracterización físico-química do depósito litoral de Mougás (Pontevedra): Implicacións morfoxenéticas. In Dinámica y Evolución de Medios Cuaternarios, 1nd ed.; Pérez Alberti, A., Martini, P., Chesworth, W., Martínez Cortizas, A., Eds.; Xunta de Galicia: Santiago de Compostela, Spain, 1996; pp. 431-440.

6. Costa-Casais, M.; Pérez-Alberti, A.; Blanco-Chao, R. Depósitos coluviales de origen nival en la costa sur de Pontevedra (Galicia): Facies y procesos deposicionales. In Estudios Recientes (2000-2002) en Geomorfología. Patrimonio, Montaña y Dinámica Territorial, 1st ed.; Serrano, E., García de Celis, A., Guerra, J.C., Morales, C.G., Ortega, M.T., Eds.; Dpto. de Geografía-Universidad de Valladolid. SEG: Valladolid, Spain, 2002; pp. 539-546.

7. Pérez Alberti, A.; Costa Casais, M.; Blanco Chao, R. L'importance des processes d'origine froide sur la cote Atlantique de la Galice (nord-ouest de la peninsule Iberique). Environ. Périglac. Bull. L'Assoc. Fr. Périglac. 1998, 5, 21-32.

8. Blanco-Chao, R.; Costa-Casais, M.; Martínez-Cortizas, A.; Pérez Alberti, A.; Trenhaile, A.S. Evolution and inheritance of a rock coast: Western Galicia, northwestern Spain. Earth Surf. Process. Landf. 2003, 28, 757-775. [CrossRef]

9. Trenhaile, A.S.; Pérez Alberti, A.; Martínez Cortizas, A.; Costa Casais, M.; Blanco Chao, R. Rock coast inheritance: An example from Galicia, Northwestern Spain. Earth Surf. Process. Landf. 1994, 24, 605-621. [CrossRef]

10. Santos-Fidalgo, M.L.; Vidal-Romaní, J.R. El lagoon de Seselle: Un episodio de la transgresión Holocena en la Ria de Ares (A Coruña, Galicia, España). Datos geomorfológicos, sedimentarios y paleoecológicos. Cuad. Lab. Geol. Laxe 1995, 18, 163-174.

11. Dias, J.M.A.; Boski, T.; Rodrigues, A.; Magalhaes, F. Coast line evolution in Portugal since the last glacial maximum until present-a synthesis. Mar. Geol. 2000, 170, 177-186. [CrossRef]

12. Freitas, M.C.; Andrade, C.; Cruces, A. The geological record of environmental changes in southwestern Portuguese coastal lagoons since the Lateglacial. Quat. Int. 2002, 93-94, 161-170. [CrossRef]

13. Freitas, M.C.; Andrade, C.; Rocha, F.; Tassinari, C.; Munhá, J.M.; Cruces, A.; Vidinha, J.; da Silva, C.M. Lateglacial and Holocene environmental changes in Portuguese coastal lagoons1: The sedimentological and geochemical records of the Santo André coastal area. Holocene 2003, 13, 433-446. [CrossRef]

14. Bao, R.; Alonso, A.; Delgado, C.; Pagés, J.L. Identification of the main driving mechanisms in the evolution of a small coastal wetland (Traba, Galicia, NW Spain) since its origin 5700 cal yr BP. Palaeogeogr. Palaeoclimatol. Palaeoecol. 2007, 247, 296-312. [CrossRef]

15. Costas-Otero, S. Origen y Evolución del Conjunto Playa-Duna-Lagoon de Cíes (Parque Nacional Marítimo-Terrestre de Las Islas Atlánticas de Galicia), 1st ed.; Organismo Autónomo Parques Nacionales. Ministerio de Medio Ambiente: Madrid, Spain, 2008; 191p.

16. Costas-Otero, S.; Muñoz Sobrino, C.; Alejo, I.; Pérez-Arlucea, M. Holocene evolution of a rock-bounded barrier lagoon system, Cíes Islands, northwest Iberia. Earth Surf. Process. Landf. 2009, 34, 1575-1586. [CrossRef]

17. Martins, V.; Jouanneau, J.M.; Weber, O.; Rocha, F. Tracing the late Holocene evolution of the NW Iberian upwelling system. Mar. Micropaleontol. 2006, 59, 35-55. [CrossRef]

18. Alvarez, M.C.; Flores, J.A.; Sierro, F.J.; Diz, P.; Francés, G.; Pelejero, C.; Grimalt, J. Millennial surface water dynamics in the Ria de Vigo during the last 5000 years as revealed by coccoliths and molecular biomarkers. Palaeogeogr. Palaeoclimatol. Palaeoecol. 2005, 218, 1-13. [CrossRef]

19. González-Álvarez, R.; Bernárdez, P.; Pena, L.D.; Francés, G.; Prego, R.; Diz, P.; Vilas, F. Paleoclimatic evolution of the Galician continental shelf (NW of Spain) during the last 3000 years: From a storm regime to present conditions. J. Mar. Syst. 2004, 54, 245-260. [CrossRef]

20. Dawson, A.; Elliott, A.; Noone, S.; Hickey, K.; Holt, T.; Wadhams, P.; Foster, I. Historical storminess and climate 'see-saws' in the North Atlantic region. Mar. Geol. 2004, 210, 247-259. [CrossRef]

21. Meeker, L.D.; Mayewski, P.A. A 1400 year high-resolution record of atmospheric circulation over the North Atlantic and Asia. Holocene 2002, 12, 257-266. [CrossRef]

22. Food and Agriculture Organization of the United Nations. A Framework for International Classification, Correlation and Communication; Food and Agriculture Organization of the United Nations: Rome, Italy, 2006.

23. Munsell Color Co. Inc. Munsell Soil Color Charts; Munsell Color Co. Inc.: Baltimore, MD, USA, 1975.

24. Trenhaile, A.S. Modeling the development of wave-cut shore platforms. Mar. Geol. 2000, 166, 163-178. [CrossRef] 
25. Trenhaile, A.S. Modeling the development of marine terraces on tectonically mobile rock coasts. Mar. Geol. 2002, 185, 341-361. [CrossRef]

26. Komar, P.D.; Gaughan, M.K. Airy wave theory and breaker height prediction. In Proceedings of the 13th Coastal Engineering Conference, American Society of Civil Engineers, Vancouver, BC, Canada, 10-14 July 1972; pp. 405-418.

27. Costa-Casais, M.; Caetano Alves, M.I. Geological heritage at risk in NW Spain. Quaternary deposists and landforms of "Southern Coast" (Baiona-A Garda). Geoheritage 2013, 5, 227-248. [CrossRef]

28. Martínez-Cortizas, A.; Moares Domínguez, C. Edafología y Arqueología: Estudio de Yacimientos Arqueológicos al Aire Libre en Galicia; Consellería de Cultura. Xunta de Galicia: Santiago de Compostela, Spain, 1995; 199p.

29. Martínez-Cortizas, A.; Fábregas Válcarce, R.; Franco Maside, S. Evolución del paisaje y actividad humana en el área de Monte Penide (Redondela, Pontevedra): Una aproximación metodológica. Trab. Prehist. 2000, 57, 173-184. [CrossRef]

30. Van Geel, B.; Buurman, J.; Waaterbolk, H.T. Archaeological and palaeoecological indications of an abrupt climate change in The Netherlands an evidence for climatological teleconnections around 2650 BP. J. Quat. Sci. 1996, 11, 451-460. [CrossRef]

31. Van Geel, B.; Heusser, C.J.; Rensen, H.; Schumans, C.J.E. Climatic change in Chile at around 2700 BP and global evidence for solar forcing: A hypothesis. Holocene 2000, 10, 659-664. [CrossRef]

32. Van Mourik, J.M. Pollen Profiles of Slope Deposits in the Galician Area (NW Spain). Ph.D. Thesis, Universiteit van Amsterdam, Amsterdam, The Netherlands, 1985; 171p.

33. Van Mourik, J.M. The use of micromorphology in soil pollen analysis. The interpretation of the pollen content of slope deposits in Galicia, Spain. Catena 1999, 35, 239-257. [CrossRef]

34. Fábregas-Valcarce, R.; Martínez-Cortizas, A.; Blanco-Chao, R.; Chesworth, W. Environmental change and social dynamics in the second-third millenium BC in NW Iberia. J. Archaeol. Sci. 2003, 30, 859-871. [CrossRef]

35. Martínez Cortizas, A.; Mighall, T.; Pombal, X.; Novoa-Muñoz, J.C.; Peiteado-Varela, E.; Piñeiro-Rebolo, R. Linking changes in atmospheric dust deposition, vegetation change and human activities in northwestern Spain during the last 5300 years. Holocene 2005, 15, 698-706. [CrossRef]

36. Martínez-Cortizas, A.; Costa-Casais, M.; López-Sáez, J.A. Environmental change in NW Iberia between 7000 and $500 \mathrm{cal}$ BC. Quat. Int. 2009, 200, 77-89. [CrossRef]

37. Martínez-Cortizas, A.; Kaal, J.; Costa-Casais, M.; Chesworth, W. Human activities and Holocene environmental change in NW Spain. In Control de la Degradación de Los Suelos y Cambio Globa, 2nd ed.; Sánchez Díaz, J., Asins Velis, S., Eds.; IV Simposio Nacional. CDSCG: Valencia, Spain, 2009; pp. 193-208.

38. Mighall, T.M.; Martínez-Cortizas, A.; Biester, H.; Turner, S.E. Proxy climate and vegetation changes during the last five millennia in NW Iberia: Pollen and non-pollen palynomorph data from two ombrotrophic peat bogs in the North Estern Iberian Peninsula. Rev. Palaeobot. Palynol. 2006, 141, 203-223. [CrossRef]

39. Kaal, J.; Costa Casais, M.; Ferro Vázquez, C.; Pontevedra Pombal, X.; Martínez Cortizas, A. Soil formation of "Atlantic Rankers" from NW Spain. A high resolution aluminium and iron fractionation study. Pedosphere 2008, 18, 441-453. [CrossRef]

40. Kaal, J.; Martínez-Cortizas, A.; Eckmeier, E.; Costa-Casais, M.; Santos-Estévez, M.; Criado-Boadio, F. Holocene fire history of black colluvial soils revealed by pyrolysis-CG/MS: A case study from Campo Lameiro (NW Spain). J. Archaeol. Sci. 2008, 35, 2133-2143. [CrossRef]

41. Mücher, H.J.; Carballas, T.; Guitián Ojea, F.; Jungerius, P.D.; Kroonenberg, S.B.; Villar, M.C. Micromorphological analysis of effects of alternating phases of landscape stability and instability on two soil profiles in Galicia, N.W. Spain. Geoderma 1972, 8, 241-266. [CrossRef]

42. Gómez-Orellana, L.; Ramil-Rego, P.; Muñoz-Sobrino, C. Una nueva secuencia polínica y cronológica para el depósito pleistoceno de Mougás (NW de la Península Ibérica). Rev. Paléobiol. 1998, 17, 35-47.

43. Carrión Marco, Y. La Vegetación Mediterránea y Atlántica de la Península Ibérica: Nuevas Secuencias Antracológicas; Servicio de Investigación Prehistórica. Serie de Trabajos Varios, núm. 104; Diputación Provincial de Valencia: València, Spain, 2005; 314p.

44. Martínez-Cortizas, A.; Pontevedra-Pombal, X.; Nóvoa Muñoz, J.C.; García-Rodeja, E. Four thousand years of atmospheric $\mathrm{Pb}, \mathrm{Cd}$ and $\mathrm{Zn}$ deposition recorded by the ombrotrophic peatbog of Penido Vello (Nortwestern Spain). Water Air Soil Pollut. 1997, 100, 387-403. [CrossRef] 
45. Martínez-Cortizas, A.; Pontevedra-Pombal, X.; Nóvoa Muñoz, J.C.; García-Rodeja, E.; Shotyk, W. Mercury in a Spanish peat bg: Archive of climate change and atmospheric metal deposition. Science 1999, 284, 939-942. [CrossRef] [PubMed]

46. Martínez-Cortizas, A.; García-Rodeja, E.; Pontevedra-Pombal, X.; Nóvoa Muñoz, J.C.; Weis, D.; Cheburkin, A. Atmospheric $\mathrm{Pb}$ deposition in Spain during the last 4.600 years record by two ombrotrophic peat bogs and implications for the use of peat as a geochemical archive. Sci. Total Environ. 2002, 292, 33-44. [CrossRef]

47. Costa-Casais, M.; Martínez-Cortizas, A.; Pontevedra-Pombal, X.; Criado-Boado, F. Analysis of landforms in geoarchaeology: Campo Lameiro, NW Iberian Peninsula. Memorie descrittive della Carta Geologica d'Italia $2009,86,39-50$. article distributed under the terms and conditions of the Creative Commons Attribution (CC BY) license (http://creativecommons.org/licenses/by/4.0/). 